\title{
Hubungan Antara Dukungan Sosial Keluarga dengan Kualitas Hidup Pada Lansia Di Nagari Paninjauan Kec. X Koto Diatas Kab. Solok
}

\author{
Ria Okfrima, Erika Prima Yola, Harry Theozard Fikri \\ Fakultas Psikologi, Universitas Putra Indonesia "YPTK" Padang, Indonesia \\ email: riaokfrima@upiyptk.ac.id, erikaprimayola17@gmail.com, harrytheozard@yahoo.com
}

\begin{abstract}
The purpose of this research is to know the relationship between family social support with the quality of elderly life in Nagari Paninjauan Kecamatan X Koto Diatas, Kabupaten Solok. The dependent variables in this study are quality of life and independent variables are family social support. The measuring instrument used in this study is the family social support scale that researchers compiled based on the theory put forward by House (in Suparni, 2016) and the quality of life scale that researchers compiled based on the theory expressed by WHO Called WHOQOL (World Health Organization Quality of Life). The population in this study was the elderly in Nagari Ogan which amounted to 291 elderly. As for the determination of the subject of this study using Simple Random Sampling technique in which the researchers mix the subjects within the population so that all subjects are considered equal, and the samples in this study were $25 \%$ of the population of 73 elderly in Nagari Paninjauan, Kabupaten Solok. The data analysis method used for the hypothesis testing in this study is to use the (Pearson) correlation of Produc moment, which indicates that rxy $=0.415$ with a value of $P=0.000(<0.01)$, which means there is a significant relationship between family social support with quality of life in the elderly in Nagari Paninjauan, Kabupaten Solok medium category. Means research hypothesis is acceptable. The effective contribution of family social support variables to the quality of life is a much as $17 \%$.
\end{abstract}

Keywords: Family Social Support, Quality of Life, Elderly

\begin{abstract}
Abstrak
Tujuan penelitian ini adalah untuk mengetahui hubungan antara dukungan sosial keluarga dengan kualitas hidup lansia di nagari Paninjauan Kecamatan X Koto Diatas, Kabupaten Solok. Variabel dependen dalam penelitian ini adalah kualitas hidup dan variabel independen adalah dukungan sosial keluarga. Alat ukur yang digunakan dalam penelitian ini adalah skala dukungan sosial keluarga yang peneliti susun berdasarkan teori yang dikemukakan oleh House (dalam Suparni, 2016) dan skala kualitas hidup yang peneliti susun berdasarkan teori yang dikemukakan oleh WHO yang disebut WHOQOL (World Health Organization Quality of Life). Populasi dalam penelitian ini adalah lansia di Nagari Paninjauan yang berjumlah 291 lansia. Adapun penentuan subjek penelitian ini menggunakan teknik Simple Random Sampling dimana peneliti mencampur subjek-subjek didalam populasi sehingga semua subjek dianggap sama, dan sampel dalam peneltian ini adalah $25 \%$ dari populasi yaitu 73 lansia yang ada di Nagari Paninjauan, Kabupaten Solok. Metode analisis data yang digunakan untuk pengujian hipotesis dalam penelitian ini adalah dengan menggunakan korelasi produc moment (Pearson), yang menunjukkan bahwa $r_{x y}=0,415$ dengan nilai $\mathrm{p}=0,000(<0,01)$, artinya terdapat hubungan yang signifikan antara dukungan sosial keluarga dengan kualitas hidup pada Lansia di Nagari Paninjauan, Kabupaten Solok dengan kategori sedang. Berarti hipotesis penelitian diterima. Adapun sumbangan efektif dari variabel dukungan sosial keluarga terhadap kualitas hidup sebanyak $17 \%$.
\end{abstract}

Kata Kunci : Dukungan Sosial Keluarga, Kualitas Hidup, Lansia

\section{Pendahuluan}

Manusia adalah makhluk yang paling istimewa di dunia ini, manusia terus mengalami perubahan (change over time), memulai kehidupan dalam kandungan ibu dimulai dari terbentuknya zigot dan kemudian berkembang menjadi embrio dan kemudian janin atau fetus. Kemudian lahir ke dunia disebut dengan infancy yaitu usia 0-2 minggu, lalu tumbuh menjadi bayi yaitu usia 2 minggu-2 tahun, kemudian kanak-kanak atau biasa disebut dengan usia emas (golden age) yang dimulai usia 2 hingga 10 tahun, remaja yaitu usia 10 hingga 19 tahun digolongkan dalam baligh kemudian berlanjut ke tahapan kehidupan manusia yang paling kompleks adalah usia dewasa yaitu usia 30 hingga 60 tahun. Kemudian lanjut usia atau lansia yaitu pada usia 60 tahun ke atas hingga meninggal [1]. Lansia adalah bagian dari proses tumbuh kembang dan di masa ini akan mengalami kemunduran fisik, mental dan sosial secara bertahap, Potter \& Perry [1] Menurut Undang-Undang Nomor 13 tahun 1998 pasal 1 ayat 2 tentang batasan lanjut usia adalah seseorang yang telah mencapai usia 60 tahun ke atas. Lanjut usia

Diterima Redaksi : 15-12-2020 | Selesai Revisi : 27-04-2021 | Diterbitkan Online : 28-04-2021 
adalah seseorang yang telah berusia 60 tahun keatas baik wanita maupun laki-laki yang secara fisik dapat dibedakan atas dua yaitu lanjut usia potensial dan lanjut usia tidak potensial. Kemajuan ilmu pengetahuan dan teknologi serta perbaikan sosial ekonomi berdampak pada peningkatan derajat kesehatan masyarakat dan usia harapan hidup, sehingga jumlah lansia juga meningkat. Sampai sekarang ini, penduduk di 11 negara anggota World Health Organization (WHO) kawasan Asia Tenggara yang berusia di atas 60 tahun berjumlah 142 juta orang dan diperkirakan akan terus bertambah hingga 3 kali lipat di tahun 2050, WHO 2012 [1]. Populasi penduduk Indonesia merupakan populasi terbanyak ke empat sesudah China, India dan Amerika Serikat. Menurut data World Health Statistik 2013, penduduk China berjumlah 1.35 milyar, India 1,24 milyar, Amerika Serikat 313 juta dan Indonesia berada di urutan keempat dengan 242 juta penduduk (WHO 2013) Menurut proyeksi Badan Pusat Statistik (2013) pada 2018 proporsi penduduk usia 60 tahun ke atas sebesar 24.754.500 jiwa $(9,34 \%)$ dari total populasi [2]. Populasi lansia meningkat sangat cepat. Tahun 2020, jumlah lansia di prediksi sudah menyamai jumlah balita [2]. Sebelas persen dari 6,9 milyar penduduk dunia adalah lansia, WHO 2013 dalam [2]. Peningkatan jumlah penduduk lansia ini akan membawa dampak terhadap berbagai kehidupan. Dampak utama peningkatan jumlah lansia ini adalah peningkatan ketergantungan lansia. Ketergantungan ini disebabkan oleh kemunduran fisik, psikis dan sosial lansia yang dapat digambarkan melalui empat tahap, yaitu kelemahan, keterbatasan fungsional, ketidakmampuan, dan keterhambatan yang akan dialami bersamaan dengan proses kemunduran akibat proses menua. Proses menua merupakan kondisi wajar dan tidak dapat dihindari dalam fase kehidupan [1]. Sumiati [3] menjelaskan bahwa menjalani lanjut usia yang bahagia dan sehat hanya dapat dicapai apabila lansia tersebut merasa sehat secara fisik, mental/spiritual dan sosial, merasa dibutuhkan, merasa dicintai, mempunyai harga diri serta dapat berpartisipasi dalam kehidupan. Dengan terpenuhinya kebutuhan tersebut, maka sudah selayaknya seorang lanjut usia memiliki kehidupan yang berkualitas. World Health Organization Quality of Life (WHOQOL) mendefinisikan kualitas hidup sebagai persepsi individu terhadap kehidupannya di masyarakat dalam konteks budaya dan sistem nilai yang ada yang terkait dengan tujuan, harapan, standar, dan perhatian. Kualitas hidup merupakan suatu konsep yang sangat luas yang dipengaruhi kondisi fisik individu, psikologis, tingkat kemandirian, serta hubungan individu dengan lingkungan [1]. Kualitas hidup lansia adalah tingkat kesejahteraan dan kepuasan dengan peristiwa atau kondisi yang dialami lansia, yang dipengaruhi oleh penyakit atau pengobatan. Kaulitas hidup lansia bisa didapatkan dari kesejahteraan hidup lansia, emosi, fisik, pekerjaan dan kehidupan sosal [4]. Econimic and Social Research Council (ESRC, 2004) [5] menyebutkan bahwa kualitas hidup dipengaruhi oleh faktor-faktor berikut ini, yaitu dukungan sosial yang baik dengan keluarga, teman dan tetangga; standar harapan hidup; keterlibatan dalam kegiatan sosial dan kegiatan amal; kegiatan hobi dan kesukaan; kesehatan yang baik dan kemampuan fungsional; rumah dan lingkungan yang baik serta perasaan aman; kepercayaan/ nilai diri positif; kesejahteraan psikologis dan emosional; pendapatan yang cukup; akses yang mudah dalam transportasi dan pelayanan; dan perasaan dihargai dan dihormati orang lain. Menurut King [5] dukungan sosial adalah informasi atau umpan balik dari orang lain yang menunjukkan bahwa seseorang dicintai dan diperhatikan, dihargai dan dihormati, dan dilibatkan dalam jaringan komunikasi dan kewajiban yang timbal balik. Dukungan keluarga memiliki peran yang besar dalam kehidupan lansia. Hurlock [6] menyebutkan bahwa psikologis dalam pola hidup lansia akan terpenuhi apabila mereka didekatkan dengan kerabat keluarga dan teman-teman sehingga kemungkinan mereka untuk sering berkomunikasi. Menurut A, Darmanto [1] pada umumnya warga lanjut usia menghadapi kelemahan, keterbatasan dan ketidakmampuan, sehingga kualitas hidup pada lanjut usia menjadi menurun. Karena keluarga adalah unit terkecil dari masyarakat, maka keluarga memiliki peranan yang sangat penting dalam perawatan lanjut usia untuk meningkatkan kualitas hidup lanjut usia. Dukungan keluarga juga penting dalam mengintensifkan perasaan sejahtera, maka adanya dukungan sosial keluarga dapat menciptakan lansia yang mandiri, percaya diri, bermartabat, dan sejahtera menurut Friedman [5]. Berdasarkan hasil wawancara yang peneliti lakukan pada tanggal 13 Oktober 2019 terhadap Wali Nagari Kenagarian Paninjauan yang berada di Kecamatan X Koto Diatas Kabupaten Solok. Di Nagari Paninjauan terdapat cukup banyak lansia. Lansia tersebut pada umumnya merupakan penduduk kelahiran asli nagari tersebut. Wali Nagari Paninjauan menjelaskan bahwa sangat sedikit lansia yang berasal dari luar Nagari Paninjauan yang menetap di Nagari Paninjauan. Lansia yang ada 
di Nagari Paninjauan rata-rata masih aktif dalam kehidupannya sehari-hari, artinya lansia tersebut masih beraktifitas seperti biasa, ada yang masih bekerja seperti mengolah lahan atau ladang, ada yang berjualan, dan sebagainya. Namun ada juga lansia yang tidak bekerja, hanya di rumah tetapi kebanyakan memiliki kesehatan yang terganggu. Keterangan yang narasumber berikan, Lansia di Nagari Paninjauan menetap di rumah yang sudah lama ia tempati meskipun sudah mengalami banyak perbaikan. Ia hidup dan meneruskan keturunan di rumah yang sama, dan tidak jarang ada bebarapa lansia yang hidup hanya dengan beberapa orang anggota keluarga saja karena angggota keluarga lainnya atau keturunannya bekerja atau betempat tinggal di luar kota. Namun ada juga lansia yang tinggal dengan pasangannya atau bahkan tinggal sendiri. Namun demikian, pada hari kebesaran tertentu, tampak ramai sekali warga di Nagari Paninjauan karena merupakan ajang berkumpul bagi keluarga. Pada saat seperti inilah biasanya terdapat banyak acara-acara kenagarian yang digelar oleh Nagari. Berdasarkan hasil wawancara yang peneliti lakukan pada tanggal 15 Oktober 2019 terhadap 2 lansia yang masing-masing berumur 78 tahun dan 69 tahun, beliau mengatakan bahwa mereka sering dilanda kesepian karena hidup berjuhan dengan anggota keluarga lainnya seperti anak dan cucu. Namun rasa syukur masih tetap tumbuh karena masih ada kesempatan untuk meneruskan hidup dan meningkatkan hubungan yang baik dengan sang pencipta. Rasa sedih juga kadang melanda di waktuwaktu tertentu, misalnya pada saat sakit namun jauh dari anak atau anggota keluarga. Kemudian, mengurus atau merawat rumah merupakan kesenangan tersendiri bagi mereka. Karena dengan begitu mereka masih aktif bergerak meskipun tidak melalukan pekerjaan berat. Berdasarkan keterangan narasumber, keluarga merupakan penyemangat utama bagi kelangsungan hidup mereka baik dari segi materil atau non-materil. Ketidakmampuan dalam mencari nafkah serta ketidakmampuan mengurus diri sendiri menjadi salah satu kesulitan yang dialami oleh lansia sehingga sangat dibutuhkan orang lain misalnya anak atau cucu untuk membantu mereka.

\subsection{Kualitas Hidup}

Menurut Cohen \& Lazarus [4] kualitas hidup adalah tingkat kepuasan atau ketidakpuasan yang dirasakan seseorang tentang berbagai aspek dalam kehidupannya. Kualitas hidup termasuk kemandirian, privacy, pilihan, penghargaan dan kebebasan bertindak. Kualitas hidup adalah tingkatan yang menggambarkan keunggulan seorang individu yang dapat dinilai dari kehidupan mereka. Keunggulan tersebut biasanya dilihat dari tujuan hidupnya, kontrol pribadinya, hubungan interpersonal, perkembangan pribadi, intelektual dan kondisi materi. Diener, dkk [7] dalam artikelnya yang berjudul Quality of Life : Definition and Measurement menyebutkan bahwa kualitas hidup adalah bagaimana seorang individu merasakan kebahagiaan hidup, yang dilihat dari kondisi emosional, kepuasan terahadap kehidupan, kepuasan terhadap pekerjaan dan kepuasan terhadap hubungan sosial. Ekasari [4] menyebutkan kualitas hidup adalah persepsi individu terhadap kesehatan fisik, sosial dan emosi yang dimilikinya, hal tersebut berkaitan dengan keadaan fisik dan emosi individu tersebut dalam kemampuannya melaksanakan ekatifitas sehari-hari yang ditunjang dengan sarana dan prasarana yang ada di lingkungan sekitar. Quality of life adalah suatu terminologi yang menunjukkan tentang kesehatan, fisik, sosial dan emosi seseorang serta kemampuannya melaksanakan tugas seharihari, Cummins dalam [7]. Kualitas hidup menurut Rebbeca, et.al [7] dalam bukunya yang berjudul Quality of Life in Health Promotion and Rehabilitastion : Concept Approaches, issues, and Applications adalah tingkatan seseorang merasa senang dengan berbagai pilihan penting dalam kehidupannya.

\subsection{Dimensi Kualitas Hidup}

Netuveli dan Blane [4] menjelaskan ada dua dimensi kualitas hidup yaitu objektif dan subjektif. Kualitas hidup digambarkan dalam rentang dari unidimensi yang merupakan domain utama yaitu kesehatan atau kebahagiaan sampai pada multidimensi dimana kualitas hidup didasarkan pada sejumlah domain yang berbeda yaitu domain objektif (pendapatan, kesehatan, lingkungan) dan subjektif (kepuasan hidup, kesejahteraan psikologis). Kualitas hidup objektif yaitu berdasarkan pada pengamatan eksternal individu seperti standar hidup, pendapatan, pendidikan, status kesehatan, umur panjang dan yang terpenting adalah bagaimana individu dapat mengontrol dan sadar mengarahkan hidupnya. Kualitas hidup dari dimensi subyektif didasarkan pada respon psikologis individu terhadap 
kepuasan dan kebahagiaan hidup. Jadi kualitas hidup subjektif adalah sebagai persepsi individu tentang bagaimana suatu hidup yang baik dirasakan oleh masing-masing individu yang memilikinya. Gurkova [4] menyebutkan domain objektif diukur dengan indikator sosial yang menggambarkan standar kehidupan dalam hubungannya dengan norma budaya. Sedangkan domain subjektif diukur berdasarkan bagaimana individu menerima menerima kehidupan yang disesuaikan dengan standar internal. Kualitas hidup merupakan persepsi individu yang didasarkan pada standar internal (nilai, harapan, aspirasi, dll). Pada lansia aspek signifikan dari penilaian kualitas hidup adalah otonomi, kecukupan diri, pengambilan keputusan, adanya nyeri dan penderitaan, kemampuan sesnsori, mempertahanka sistem dukungan sosial, tingkat finansial tertentu, perasaan berguna bagi orang lain dan tingkat kebahagiaan.

\subsection{Dukungan Sosial Keluarga}

Menurut Cohen \& Sme [8] dukungan sosial keluarga adalah suatu keadaan yang bermanfaat bagi individu yang diperoleh dari orang lain yang dapat dipercaya, sehingga seseorang akan tahu bahwa ada orang lain yang memperhatikan, menghargai dan mencintainya. Dukungan sosial keluarga adalah sebagai suatu proses hubungan antara keluarga dengan lingkungan sosial Friedman [9]. Dukungan sosial keluarga menurut House dan Kahn [8] dukungan sosial merupakan tindakan yang bersifat membantu yang melibatkan emosi, pemberian informasi, bantuan instrumen, dan penilaian positif pada individu dalam menghadapi permasalahannya. Menurut Sarafino [8] dukungan sosial merupakan cara untuk menunjukkan kasih sayang, kepedulian, dan penghargaan untuk orang lain. Individu yang menerima dukungan sosial akan merasa dirinya dicintai, dihargai, dan merupakan bagian dari lingkungan sosialnya. Menurut Harnilawati [8] dukungan sosial keluarga menjadikan keluarga mampu berfungsi dengan berbagai kepandaian dan akal, sehingga akan meningkatkan kesehatan dan adaptasi mereka dalam kehidupan.

\subsection{Dimensi Dukungan Sosial}

Menurut House [9] dimensi dukungan sosial terdiri dari empat dimensi, yaitu:

a. Dukungan emosional : dukungan ini meliputi ungkapan empati, kepedulian, dan perhatian terhadap orang yang bersangkutan. $b$. Dukungan penghargaan : dukungan ini terjadi lewat ungkapan hormat atau penghargaan positif untuk orang lain, suatu dorongan untuk maju atau persetujuan dengan gagasan atau perasaan individu, dan perbandingan positif orang itu dengan orang lain. c. Dukungan instrumental : dukungan ini meliputi bantuan secara langsung sesuai dengan yang dibutuhkan oleh seseorang seperti, seperti pemberian dana, pemenuhan buku-buku sarana pendidikan lainnya, serta kesediaan keluarga meluangkan waktu untuk berdialog atau senantiasa siap memberikan pertolongan ketika dibutuhkan oleh remaja. d. Dukungan informatif : dukungan ini berupa pemberian nasihat, petunjuk-petunjuk, saran-saran, pengetahuan, dan informasi.

\section{Metode Penelitian}

Jenis penelitian ini adalah kuantitatif korelasional dengan variabel penelitian menurut Sugiyono [10] variabel Dependen, penelitian Kualitas Hidup (Y) dan Variabel Independen, Dukungan Sosial Keluarga (X). Populasi pada penelitian ini adalah lansia di Nagari Paninjauan Kec. X Koto Diatas, Kab. Solok yang berjumlah 291 orang. Teknik pengambilan sampel dalam penelitian ini adalah sample random sampling karena pegambilan anggota sampel dari populasi dilakukan secara acak tanpa memperhatikan strata yang ada dalam populasi itu. Dalam menentukan ukuran sampel peneliti menggunakan 25\% dari populasi menurut Arikunto [11] sehingga diperoleh 73 lansia sebagai sampel penelitian. Metode pengumpulan data yang digunakan dalam penelitian ini adalah skala model likert untuk mendapatkan data kuantitatif. Skala ini digunakan untuk mengukur sikap, pendapat, dan persepsi seseorang atau sekelompok orang tentang fenomena sosial, Sugiyono [10]. Skala yang digunakan pada kualitas hidup dan skala dukungan sosial keluarga adalah model likert. Format skala yang digunakan merupakan format yang telah dimodifikasi menjadi empat alternatif jawaban yaitu SS (Sangat Setuju), S ( Setuju), TS (Tidak Setuju), dan STS (Sangat Tidak Setuju). Aitem-aitem dalam skala ini dikelompokkan dalam item favourable dan unfavourable. Skala penelitian akan melewati berbagai tahap analisis yaitu uji normalitas digunakan untuk mengetahui apakah populasi data 
terdistribusi normal atau tidak. Uji normalitas menggunakan uji kolmogorov-Smirnov. Uji linearitas bertujuan untuk mengetahui apakah dua variabel mempunyai hubungan yang linear atau tidak. Dua variabel dikatakan mempunyai hubungan yang linear bila signifikasi (linearty) kurang dari 0,05. Selain itu dilakukan uji Validitas, sejauh mana ketepatan dan kecermatan suatu alat ukur dalam melakukan fungsi ukurnya, Azwar [12]. Suatu item dapat dianggap memiliki daya diskriminasi yang memuaskan jika berkorelasi signifikan terhadap skor total atau jika melakukan penilaian langsung terhadap koefisien korelasi bisa digunakan batas nilai berkriteria rxy $\geq 0,3$, Azwar [12]. Data skala dikatakan memiliki daya beda tinggi jika koefisien korelasi lebih besar atau sama dengan 0,3 (rxy $\geq$ $0,3)$ dan sebaliknya aitem skala dikatakan gugur jika koefisien korelasi lebih kecil dari 0,3 (rxy $\geq 0,3$ ).

\section{Hasil dan Pembahasan}

Peneliti menyebarkan 73 skala Kualitas Hidup dan skala Dukungan Sosial Keluarga dan meminta kesediaan kepada lansia untuk mengisi skala kemudian menjelaskan cara pengisian skala dengan cara memberikan skala secara langsung kepada lansia di Nagari Paninjauan. Sebelum pengisian skala dilakukan, peneliti terlebih dahulu memberitahukan petunjuk pengisian dengan singkat dan jelas.

\subsection{Hasil}

Koefisien Validitas skala Kualitas Hidup dengan nilai corrected item-total correlation berkisar antara 0,335 sampai dengan 0,746. dengan reabilitas 0,900, validitas skala Dukungan Sosial Keluarga dengan nilai corrected item-total correlation berkisar antara 0,335 sampai dengan 0,594, dengan reabilitas 0,905. Uji normalitas dalam penelitian ini menggunakan uji Kolmogorov-Smirnov. Arikunto [11] menyatakan bahwa data yang dinyatakan berdistribusi normal jika signifikansi (p) lebih besar dari 0,05. Berdasarkan hasil pengolahan data dengan menggunakan program IBM SPSS 21.0, Maka diperoleh hasil sebagai berikut:

Tabel 1. Uji Normalitas Skala Dukungan Sosial Keluarga dengan Kualitas Hidup

\begin{tabular}{ccccc}
\hline Variabel & N & KSZ & P & Sebaran \\
\hline Dukungan Sosial Keluarga & 73 & 0.804 & 0.537 & Normal \\
Kualitas Hidup & 73 & 0.611 & 0.849 & Normal \\
\hline
\end{tabular}

Berdasarkan uraian tabel di atas, maka diperoleh nilai signifikan pada skala Kualitas Hidup diperoleh dengan nilai signifikan sebesar $\mathrm{p}=0,849$ dengan $\mathrm{KSZ}=0,611$ hasil tersebut menunjukan bahwa nilai $\mathrm{p}>0,05$ artinya sebaran berdistribusi secara normal, sedangkan skala Dukungan Sosial sebesar $\mathrm{p}=$ 0,537 dengan $\mathrm{KSZ}=0,804$. Hasil tersebut menunjukan bahwa nilai $\mathrm{p}>0,05$ artinya sebaran berdistribusi secara normal. Selanjutnya uji linearitas dapat dilihat pada tabel 2 berikut:

Tabel 2. Uji Linieritas Skala Dukungan Sosial Keluarga dengan Kualitas Hidup

\begin{tabular}{ccccc}
\hline $\mathbf{N}$ & Df & Mean Square & F & Sig \\
\hline $\mathbf{7 3}$ & 1 & 549,231 & 17,021 & 0.000 \\
\hline
\end{tabular}

Berdasarkan uraian tabel di atas, maka diperoleh nilai signifikansi sebesar $p=0,000(p<0,05)$, dapat disimpulkan bahwa antara variabel Dukungan Sosial Keluarga dan Kualitas Hidup terdapat hubungan yang linier.

Tabel 3. Hasil Uji Korelasi Antara Dukungan Sosial Keluarga dengan Kualitas Hidup

\begin{tabular}{ccccc}
\hline $\mathbf{P}$ & $(\boldsymbol{\alpha})$ & Nilai Korelasi $(\mathbf{r})$ & $\mathbf{R}$ square & Kesimpulan \\
\hline 0,000 & 0.01 & 0,415 & 0,173 & $\begin{array}{c}\text { sig (2-tailed) } 0,000<0,01 \text { level of } \\
\text { significant }(\alpha), \text { berarti hipotesis } \\
\text { diterima. }\end{array}$ \\
\hline
\end{tabular}

Berdasarkan tabel 4.5 didapatkan $\mathrm{p}=0,000<0,01$ level of significant $(\alpha)$, sesuai dengan pernyataan Ningrum [13] terdapat hubungan yang signifikan antara Dukungan Sosial Keluarga dengan Kualitas Hidup pada Lansia di Nagari Paninjauan, Kec. X Koto Diatas, Kab. Solok. Koefisien korelasi antara variabel Dukungan Sosial Keluarga dengan Kualitas Hidup diperoleh sebesar $r=0,415$ dengan taraf 
signifikansi $\mathrm{p}=0,000$. Hal ini menunjukkan adanya korelasi yang berarah positif atau searah antara kedua variabel tersebut, yang artinya jika Dukungan Sosial Keluarga tinggi, maka Kualitas Hidup pada Lansia di Nagari Paninjauan juga tinggi, dan begitu juga sebaliknya.

Tabel 4. Descriptive Statistic

\begin{tabular}{lllccc}
\hline \multicolumn{1}{c}{ Variabel } & N & Mean & Std. Deviation & Minimum & Maximum \\
\hline Dukungan Sosial & 73 & 97,66 & 10,390 & 72 & 118 \\
keluarga & 73 & 75,68 & 6,650 & 64 & 95 \\
Kualitas Hidup & & & & & \\
\hline
\end{tabular}

Berdasarkan nilai mean empirik, maka dapat dilakukan pengelompokan yang mengacu pada kriteria pengkategorisasian dengan tujuan menempatkan individu dalam kelompok-kelompok yang terpisah secara berjenjang menurut suatu kontinum berdasarkan atribut yang diukur.

\begin{tabular}{ccccc}
\multicolumn{6}{c}{ Tabel 5. Kategori Dukungan Sosial Keluarga dengan Kualitas Hidup } \\
\hline Variabel & Skor & Jumlah & Persentase (\%) & Kategori \\
\hline \multirow{2}{*}{ Dukungan Sosial } & $72-86$ & 13 & $17,8 \%$ & Rendah \\
Keluarga & $87-107$ & 46 & $63,0 \%$ & Sedang \\
& $108-118$ & 14 & $19,2 \%$ & Tinggi \\
& $64-68$ & 13 & $17,8 \%$ & Rendah \\
Kualitas Hidup & $69-81$ & 47 & $64,4 \%$ & Sedang \\
& $82-95$ & 13 & $17,8 \%$ & Tinggi \\
\hline
\end{tabular}

Berdasarkan tabel di atas dapat digambarkan bahwa 13 orang $(17,8 \%)$ lansia memiliki Dukungan Sosial Keluarga yang rendah, 46 orang $(63,0 \%)$ lansia memiliki Dukungan Sosial Keluarga yang sedang dan 14 orang $(19,2 \%)$ lansia memiliki Dukungan Sosial Keluarga yang tinggi. Sementara itu ada 13 orang $(17,8 \%)$ lansia memiliki kulitas hidup yang rendah, 47 orang $(64,4 \%)$ lansia memiliki kulitas hidup yang sedang dan 13 orang $(17,8 \%)$ lansia memiliki kulitas hidup yang tinggi.

\subsection{Pembahasan}

Berdasarkan hasil uji korelasi Product Moment (Pearson) yang dilakukan dengan bantuan SPSS versi 21.0, diperoleh nilai koefisien korelasi $(r)=0,415$ dengan nilai $(\mathrm{p})$ sig $=0,000$, karena nilai $(\mathrm{p})$ sig $0,000<0,01$ maka hipotesis diterima. Hasil ini menunjukkan bahwa terdapat hubungan yang signifikan antara dukungan sosial keluarga dengan kualitas hidup pada pada lansia di Nagari Paninjauan, Kec. X Koto Diatas, Kab. Solok dengan arah positif artinya jika dukungan sosial keluarga tinggi, maka kualitas hidup juga tinggi, begitu juga sebaliknya jika dukungan sosial keluarga rendah maka kualitas hidup juga rendah. Hubungan yang signifikan ini menunjukkan kontribusi yang positif antara dukungan sosial keluarga dengan kualitas hidup tergolong sedang berdasarkan pengkategorisasian interpretasi koefisien korelasi, Sugiyono dalam Priyatno [14]. Hal ini sejalan dengan penelitian yang dilakukan oleh Ningrum, et al [13] yang berjudul Hubungan Dukungan Sosial Keluarga terhadap Kualitas Hidup Lansia (Studi Kasus : Kelurahan Sukamiskin Bandung) menyatakan bahwa terdapat pengaruh positif variabel Dukungan Sosial Keluarga terhadap Kualitas Hidup dengan taraf nilai yang signifikan. Menurut penelitian Yulianti [1] dengan judul Hubungan Dukungan Sosial Keluarga dengan Kualitas Hidup Lansia di Desa Ponungrejo Purworejo memberikan kesimpulan yang sama bahwa Dukungan Sosial Keluarga mempunyai pengaruh positif terhadap Kualitas Hidup. Pendapat Ekasari, et al [4] dukungan dari keluarga dapat memperngaruhi kualitas hidup lansia, seperti pemberian rasa aman, diterima dan dicintai serta memberikan kebahagiaan dalam kehidupannya sehingga dapat meningkatkan kualitas hidup lansia. Beberapa temuan penelitian diatas mendukung penelitian sebelumnya yang membuktikan bahwa Dukungan Sosial Keluarga mempunyai hubungan positif dan signifikan dengan Kualitas Hidup.

Adapun sumbangan efektif dari variabel Dukungan Sosial Keluarga terhadap Kulitas Hidup sebesar $17 \%$ sedangkan $83 \%$ sisanya dipengaruhi oleh faktor-faktor lain. Faktor lain yang dapat mempengaruhi kulitas hidup seperti faktor fisik seperti kecacatan dan rasa sakit, faktor psikologis 
seperti suasana hati, tingkat kecemasan dan depresi, dan terakhir faktor sosial seperti tingkat isolasi dari lingkungan, peluang untuk melakukan peran sosial, Siegrist and Junge [1].

\section{Kesimpulan}

Berdasarkan hasil pengumpulan data dan analisis data yang telah dilakukan oleh peneliti, maka dapat ditarik kesimpulan yang sekaligus merupakan jawaban dari tujuan penelitian yaitu terdapat hubungan yang signifikan antara Dukungan Sosial Keluarga dengan Kulitas Hidup pada pada Lansia di Nagari Paninjauan, Kec. X Koto Diatas, Kab. Solok dengan arah positif artinya jika Dukungan Sosial Keluarga tinggi, maka Kulitas Hidup juga tinggi, begitu juga sebaliknya jika Dukungan Sosial Keluarga rendah maka Kulitas Hidup juga rendah. Adapun sumbangan efektif variabel Dukungan Sosial Keluarga terhadap Kualitas Hidup adalah sebesar 17\% sedangkan $83 \%$ sisanya dipengaruhi oleh faktor-faktor lain.

\section{Daftar Rujukan}

[1] Yulianti, Amalia, et al. 2014. Perbedaan Kualitas Hidup Lansia yang Tinggal di Komunitas dengan di Pelayanan Sosial Lanjut Usia. Jurnal Kesehatan Masyarakat, Vol 2 (No. 1). Januari 2014.

[2] Permatasari, Henny, et al. 2018. Peningkatan Kualitas Hidup Lanjut Usia (Lansia) di Kota Depok dengan Latihan Keseimbangan. Jurnal Keperawatan Indonesia, Vol 21 No. 2. Halaman 109-116, 2 Juli 2018.

[3] Yuzefo, Mira Afnesta, dkk. 2015. Hubungan Status Spiritual dengan Kualitas Hidup pada Lansia. Jurnal Keperawatan, Vol 2 No. 2. Oktober 2015.

[4] Ekasari, Nia Fatma, dkk. 2018. Meningkatkan kualitas Hidup Lansia : Konsep dan berbagai strategi intevensi. Jakarta: Wineka Media.

[5] Yulianti, Ika Septia, 2017. Gambaran Dukungan Sosial Keluarga dan Kualitas Hidup Lansia dengan Hipertensi di Puskesmas Citangkil Kota Cilegon. Skripsi Keperawatan. Universitas Islam Negeri Syarif Hidayatullah.

[6] Atmaja, Rizka Ahadiningtyas Juliana Atmaja. Peran Dukungan Sosial Keluarga Terhadap Motivasi Menjaga Kesehatan Melalui Aktivitas Fisik pada Lansia. Jurnal Psikologi. Universitas YARSI. Volume 5, N0. 2. Desember 2017.

[7] Nurrizka, Rahmah Hida. 2019. Kesehatan Ibu dan Anak : dalam Upaya Kesehatan Masyarakat. Depok: PT Rajawali Pers.

[8] Harnilawati. 2013. Konsep dan Proses Keperawatan Keluarga. Makassar: Pustaka As Salam.

[9] Suparni, Ita Eko \& Reni Yuli Astutik. 2016. Menopause : Masalah dan Penanganannya. Yogyakarta : Deepublish CV Budi Utama.

[10] Sugiyono. 2014. Metode Penelitian Kuantitatif Kualitatif dan R \& D. Bandung: Alfabeta.

[11] Arikunto, Suharsimi, Prosedur Penelitian : Suatu Pendekatan Praktik, Edisi Revisi VI, Jakarta : PT Rineka Cipta, 2006

[12] Azwar, Saifuddin. 2017.Metode Penelitian Psikologi. Yogyakarta: PustakaPelajar.

[13] Ningrum, Tita Puspita, dkk. 2017. Hubungan Dukungan Keluarga dengan Kualitas Hidup Lansia (Studi Kasus : Kelurahan Sukamiskin Bandung). Jurnal Keperawatan, Universitas BSI. Vol. V. No. 2. 2 September 2017.

[14] Priyatno, Dwi. 2008. Mandiri Belajar SPSS. Yoyakarta: PT Buku Kita. 